\title{
Settling of blackcurrant and high bush blueberry by aphids
}

\section{Zasiedlanie porzeczki czarnej i borówki wysokiej przez mszyce}

\author{
Joanna Wróblewska ${ }^{1}$, Anna Tomczyk ${ }^{1}$, Elżbieta Cichocka ${ }^{2}$
}

\section{Summary}

The aim of the study was to determine the species of aphids attacking bushes of ecological plantation of blackcurrant and productive plantations of different cultivars of high bush blueberry and monitoring of the development of their colonies during seasons 2011-2012 on the cultivars: Titania (blackcurrant), and Bluecrop, , Herbert, Nelson, Duke, Patriot (blueberry). Simultaneous feeding of two aphid species: Aphis schneideri Börn. and Cryptomyzus ribis L. on the black currant plants was detected, with the domination of $A$. schneideri. In the season of 2012 average number of apids in one colony on blackcurrant shoots was 97 . All cultivars of blue berry were settled with aphids in very low numbers, especially in 2011 by two species of aphids: Myzus persicae Sulz and Aphis fabae Scop. In the seasons 2011 and 2012 an average numbers of speciments in the colonies of both aphid species was 6 and 19 , respectively.

Key words: black currant, high bush blueberry, development of aphid colonies

\section{Streszczenie}

Celem badań było określenie, jakie gatunki mszyc występują w uprawie ekologicznej porzeczki czarnej i na plantacjach towarowych różnych odmian borówki wysokiej oraz zbadanie dynamiki rozwoju ich kolonii w sezonach 2011-2012 na odmianach: Titania (czarna porzeczka), Bluecrop, Herbert, Nelson, Duke, Patriot (borówki wysoka). Na porzeczce czarnej stwierdzono jednoczesne żerowanie dwóch gatunków mszyc: mszycy porzeczkowej (Aphis schneideri Börn.) i mszycy porzeczkowo-czyściecowej (Cryptomyzus ribis L.), z wyraźną przewagą mszycy porzeczkowej. W sezonie 2012 średnia liczebność kolonii mszyc na porzeczce czarnej liczyła 97 osobników. Wszystkie odmiany borówki wysokiej były zasiedlane w niewielkim stopniu, zwłaszcza w sezonie 2011, przez dwa gatunki mszyc: mszycę brzoskwiniową (Myzus persicae Sulz.) i mszycę burakową (Aphis fabae Scop.). W latach 2011 i 2012 średnia liczebność kolonii obu gatunków mszyc wynosiła odpowiednio 6 i 19 osobników.

Słowa kluczowe: czarna porzeczka, borówka wysoka, rozwój kolonii mszyc

\footnotetext{
${ }^{1}$ Szkoła Główna Gospodarstwa Wiejskiego w Warszawie

Katedra Entomologii Stosowanej

Nowoursynowska 166, 02-787 Warszawa

anna_tomczyk@sggw.pl

${ }^{2}$ Katolicki Uniwersytet Lubelski Jana Pawła II w Lublinie

Katedra Ochrony Przyrody

Al. Racławicka 14, 20-950 Lublin

cichocka@kul.lublin.pl
} 


\section{Wstęp / Introduction}

Areał upraw porzeczki czarnej (Ribes nigrum L.) i borówki wysokiej Vaccinium corymbosum L. w Polsce cały czas rośnie, wymuszając na producentach dbanie o coraz lepszą jakość uprawianych roślin i uzyskiwanych owoców. Znaczący wpływ na kondycję roślin oraz jakość plonu mają roślinożerne stawonogi, w tym różne gatunki mszyc (Łabanowska 2007, 2012).

Porzeczka czarna jest dobrym żywicielem dla kilku gatunków mszyc, zarówno jednodomnych, jak i dwudomnych. Jaja składane są jesienią na pędach, co umożliwia rozwój kolonii mszyc już wczesną wiosną (Mitchell i wsp. 2011). Żerowanie dużych liczebnie kolonii mszyc doprowadza często do silnych uszkodzeń wierzchołkowych części pędów i jest przyczyną osłabienia kwitnienia i plonowania roślin (Cichocka 1980).

Na borówce wysokiej mogą występować głównie trzy gatunki mszyc: mszyca brzoskwiniowa (Myzus persicae Sulzer), mszyca burakowa (Aphis fabae Scop.) oraz mszyca borówkowa (Amphorophora borsalis Mason) (Łabanowska 2007). Borówka wysoka w naszych warunkach klimatycznych jest dla mszyc żywicielem wtórnym, co sprawia, że rośliny są zasiedlane przez mszyce późną wiosną i wielkość populacji może być mniejsza

niż w przypadku roślin będących żywicielami pierwotnymi (Labanowska 2012).

Liczebność kolonii mszyc na obu krzewach owocowych zależy zarówno od gatunku mszycy, jak i od warunków pogodowych.

Celem badań było określenie gatunków mszyc występujących zarówno na krzewach porzeczki czarnej, jak i borówki wysokiej oraz zbadanie rozwoju mszyc w ciagu sezonu wegetacyjnego.

\section{Materiały i metody / Materials and methods}

Badania prowadzono w latach 2011-2012, w warunkach polowych, na polu doświadczalnym Katedry Entomologii Szkoły Głównej Gospodarstwa Wiejskiego w Warszawie oraz na plantacjach towarowych położonych na terenie Mazowsza. Obserwacje prowadzono nad zasiedlaniem przez mszyce porzeczki czarnej odmiany Titania i borówki wysokiej odmian: Bluecrop, Herbert, Nelson, Duke i Patriot.

W przypadku porzeczki czarnej wybrano i oznaczono 11 krzewów z plantacji ekologicznej, na których zaobserwowano mszyce. Obserwacje prowadzono na dwóch zasiedlonych przez nie pędach z każdego oznaczonego krzewu. W celu określenia występujących gatunków mszyc prowadzono obserwację uszkodzeń powodowanych przez szkodniki, jak również pobrano próbki w celu dokładnej identyfikacji żerujących mszyc. Do probówek z $80 \%$ roztworem etanolu pobrano po kilka osobników z losowo wybranych, obserwowanych pędów.

Obserwację nad rozwojem mszyc na porzeczce rozpoczęto od lustracji pędów na obecność jaj złożonych przez samice jesienią 2011 roku.
Liczbę zimujących jaj na pędach porzeczki określano w pierwszej połowie października, a następnie powtórzono w marcu 2012 roku, gdyż ciepła jesień 2011 roku znacznie wydłużyła okres składania jaj przez mszyce. Wybrano losowo 200 pędów (średnia długość $20 \mathrm{~cm}$ ) z krzewów rosnących w różnych miejscach plantacji. Pędy oglądano pod binokularem oraz liczono złożone jaja.

Rozwój kolonii mszyc obserwowano badając liczebność populacji mszyc od momentu pojawienia się pierwszych osobników pochodzących z zimujących jaj. Liczono łącznie osobniki wszystkich rozwijających się gatunków na 2 pędach $\mathrm{z}$ każdego wybranego krzewu. Określano średnią liczbę mszyc występujących na pojedynczym pędzie, aż do momentu zaniku populacji. Dwukrotnie, w odstępach 10-dniowych (9.05 i 19.05), określano procent zasiedlonych pędów na krzewie. Dalszych obserwacji nad zasiedlaniem porzeczki przez mszyce nie prowadzono, gdyż już 19.05, prawie na wszystkich pędach stwierdzono kolonie mszyc.

Do badań borówki wysokiej wybrano i oznaczono po 10 krzewów z każdej badanej odmiany. Obserwacje prowadzono na każdym pędzie badanych roślin, który został zasiedlony przez mszyce. W celu określenia występujących gatunków mszyc obserwowano uszkodzenia powodowane przez żerujące mszyce oraz pobrano próbki w celu identyfikacji szkodnika. Wielkość populacji określano poprzez obserwacje jej od momentu przylotu szkodnika z żywiciela pierwotnego na badane rośliny. Monitorowano wielkość populacji co dwa tygodnie, aż do momentu prawdopodobnego przelotu szkodnika z powrotem na żywiciela pierwotnego w celu złożenia jaj. Badano średnią liczebność mszycy występującej na 10 krzewach z każdej odmiany.

W przypadku określania liczebności populacji mszyc, na krzewach porzeczki i borówki, wyliczano wartości błędu standardowego (SE).

\section{Wyniki i dyskusja / Results and discussion}

$\mathrm{Na}$ porzeczce czarnej wykazano obecność następujących gatunków mszyc: mszycy porzeczkowej (Aphis schneideri Börn.) i mszycy porzeczkowo-czyściecowej (Cryptomyzus ribis L.). Żerowanie tych gatunków spowodowało typowe objawy takie, jak: deformacje, chlorozy, spadź i pseudowyrośla, które są opisywane w literaturze (Cichocka 1980; Mitchell i wsp. 2011). Jaja obydwu gatunków mszyc zimują na porzeczce. Dominującym gatunkiem była mszyca porzeczkowa, która jest jednodomna i może osiagnnąć dużą liczebność.

Przeprowadzone lustracje w okresie bezlistnym wykazały obecność zimujących jaj mszyc prawie na każdym $\mathrm{z}$ badanych pędów porzeczki. Liczbę złożonych jaj przez obydwa gatunki mszyc na 200 pędach porzeczki przedstawiono na rysunku 1 . Wczesną jesienią samice złożyły na zimowanie ponad $1 / 3$ ogólnej liczby jaj znalezionych na pędach porzeczki w obu terminach obserwacji (około 100 z 375). Większość jaj została więc złożona późną jesienią. Po uwzględnieniu długości pobranych pędów $(20 \mathrm{~cm})$ liczba zimujących jaj wyniosła 9,4 na 1 m pędu. 


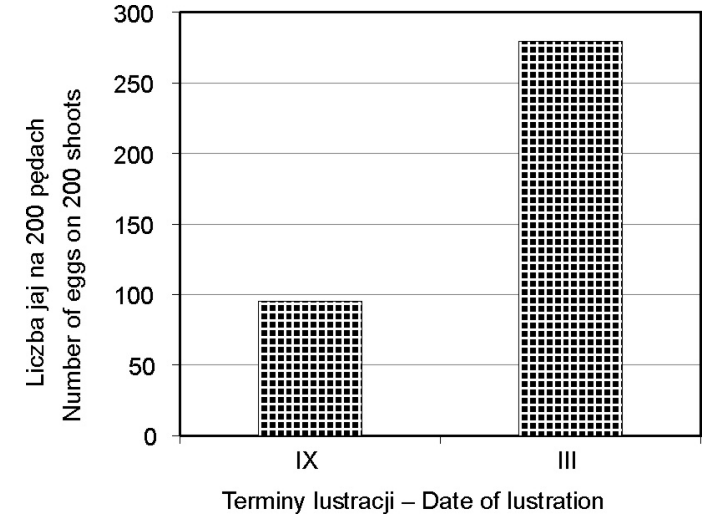

Rys. 1. Liczba jaj złożonych przez mszyce na porzeczce czarnej Fig. 1. Number of eggs laid by aphids on blackcurrant

Wiosną obserwowano na pędach porzeczki czarnej duże kolonie mszycy porzeczkowej i pojedyncze, małe kolonie mszycy porzeczkowo-czyściecowej. Zmiany liczebności populacji mszycy porzeczkowej przedstawiono na rysunku 2. Największą kolonię tej mszycy zaobserwowano na porzeczce w maju. Średnia liczebność kolonii wynosiła wówczas 98 osobników na pęd. Liczebność kolonii mszyc tego gatunku zmniejszała się wyraźnie od połowy maja prawdopodobnie $\mathrm{z}$ powodu wystąpienia takich czynników ograniczających, jak: upały, brak pożywienia, czy obecność wrogów naturalnych (zaobserwowano liczny pojaw larw biedronek). W niektórych sezonach obserwowano liczne kolonie tej mszycy także w czasie miesięcy letnich (Cichocka 1980). Mszyca porzeczkowo-czyściecowa opuszcza porzeczkę czarną późną wiosną, przelatując na żywiciela wtórnego, którym jest czyściec $\mathrm{i}$ jasnota.

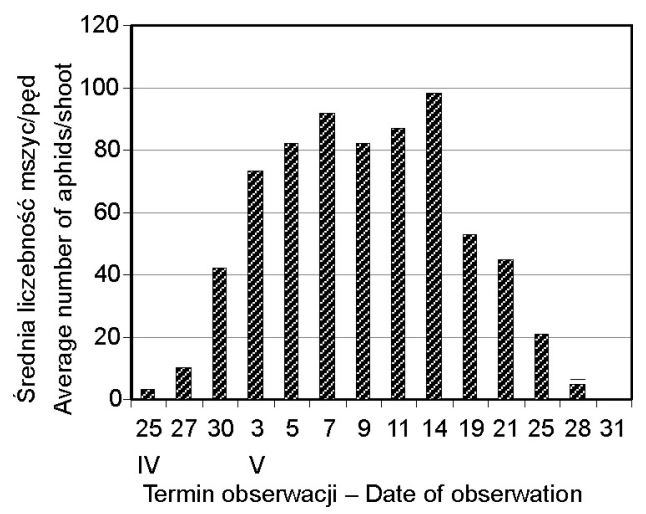

Rys. 2. Zmiany populacji mszyc na porzeczce czarnej w czasie sezonu wegetacyjnego 2012. Zaprezentowano wartości SE

Fig. 2. Changes in the population of aphids on blackcurrant during the 2012 growing season. SE values are presented

Zasiedlenie pędów porzeczki czarnej przez A. schneideri przedstawiono na rysunkach 3. i 4 . Obserwacje wykonano dwukrotnie - na początku maja i w połowie czerwca. Już na początku maja pędy były zasiedlone na każdym krzewie od 40 do $82 \%$, co dało średnie zasiedlenie na poziomie $64 \%$. W drugiej połowie maja zasiedlenie pędów większości badanych krzewów wyniosło 100\%.

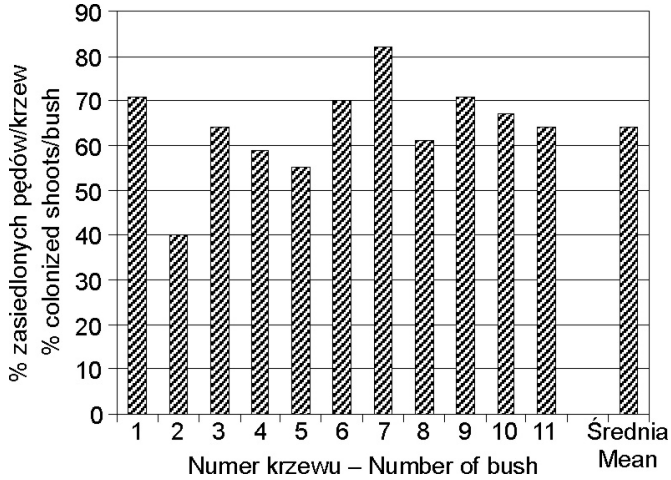

Rys. 3. Zasiedlenie pędów porzeczki czarnej przez A. schneideri (termin I)

Fig. 3. Colonization of blackcurrant's shoots by A. schneideri (term I)

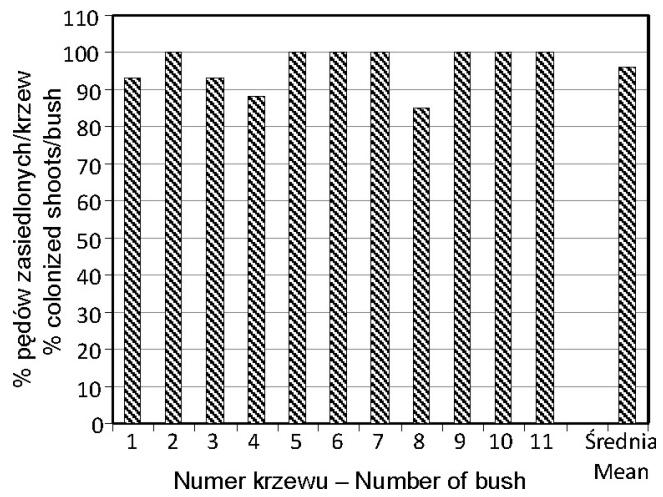

Rys. 4. Zasiedlenie pędów porzeczki czarnej przez $A$. schneideri (termin II)

Fig. 4. Colonization of blackcurrant's shoots by A. schneideri (term II)

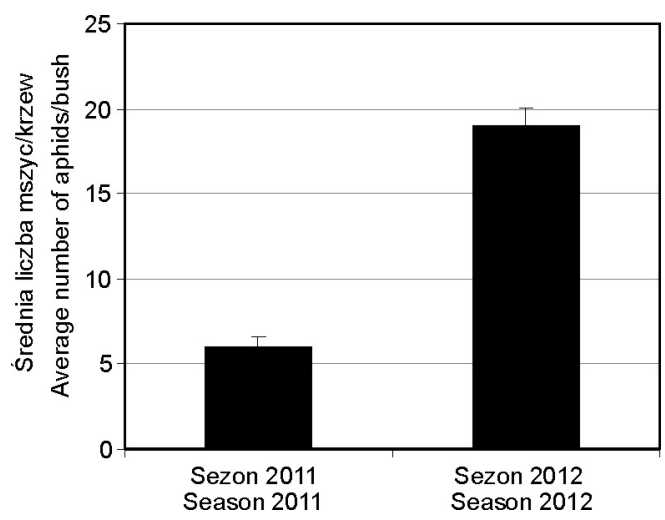

Rys. 5. Liczebność populacji mszyc na borówce wysokiej w sezonach wegetacyjnych 2011 i 2012. Zaprezentowano wartości SE

Fig. 5. The size of aphid population in the highbush blueberry in the 2011 and 2012 growing seasons. SE values are presented

W przypadku borówki wysokiej obserwowano występowanie mszycy brzoskwiniowej (Myzus persicae Sulz.) i mszycy burakowej (Aphis fabae Scop.), na dwóch spośród badanych odmian borówki - Patriot i Bluecrop. Badania innych autorów wykazały, że rośliny uszkodzone 
przez te gatunki mszyc charakteryzuja się osłabionym wzrostem, deformacją liści oraz więdnięciem pędów, a także obecnością chlorotycznych plam na liściach (Emden i Harrington 2007; Capinera 2008).

$\mathrm{Na}$ roślinach badanych odmian populacja była na tyle nieliczna, iż oprócz niewielkich deformacji liści nie zaobserwowano innych widocznych uszkodzeń. Może to mieć związek $\mathrm{z}$ faktem, że dla obu stwierdzonych gatunków borówka wysoka jest jednym z wielu żywicieli (Łabanowska 2012).

Liczebność mszyc na borówce wysokiej w sezonach wegetacyjnych 2011 i 2012 przedstawiono na rysunku 5 . Mszyce w większej liczebności wystąpiły tylko na dwóch odmianach: Patriot i Bluecrop. Obserwacje prowadzono od momentu pojawienia się pierwszych osobników na przełomie czerwca i lipca. Liczebność mszycy na borówce w sezonie 2011 była bardzo mała i wynosiła średnio 6 osobników na krzew. Położenie plantacji w pobliżu siedlisk wielu wrogów naturalnych, jak również warunki atmosferyczne panujące w sezonie 2011, w tym ulewne deszcze, nie pozwoliły na intensywny rozwój kolonii mszyc. W sezonie 2012, w którym panowały lepsze warunki pogodowe, liczebność kolonii mszyc była większa i wyniosła 19 osobników na krzew.

$\mathrm{Na}$ badanych plantacjach borówki wysokiej nie stwierdzono występowania mszycy borówkowej (Illinoia pepperi
McGillivray), atakującej plantacje borówki w Ameryce Północnej i na południu Europy (Ranger i wsp. 2006; Pansa i Tavella 2008).

\section{Wnioski / Conclusions}

1. Znaczenie mszyc jako szkodników jest wyraźnie większe na porzeczce czarnej niż na borówce wysokiej, przede wszystkim ze względu na liczne występowanie jednodomnego gatunku - A. schneideri.

2. Bezpośrednie uszkodzenia powodowane przez mszyce są większe na porzeczce czarnej niż na borówce wysokiej. Przyczyną może być fakt, że porzeczka czarna jest żywicielem pierwotnym dla zasiedlających ją gatunków mszyc, przez co szkodniki te mogą żerować na niej we wczesnych fazach rozwojowych i przez dłuższy okres sezonu wegetacyjnego w porównaniu z borówką wysoką.

3. Niższa liczebność mszyc stwierdzona na borówce wysokiej, w stosunku do porzeczki czarnej, była prawdopodobnie spowodowana polifagizmem zasiedlających ją gatunków, wybierających chętniej innych żywicieli.

\section{Literatura / References}

Capinera J.L. 2008. Green peach aphid, Myzus persicae (Sulzer) (Insecta: Hemiptera: Aphididae). p. 1727-1730. In: "Encyclopedia of Entomology" Edition (J.L. Capinera, ed.) 2nd ed. Springer, Dordrecht, The Netherlands, 4346 pp.

Cichocka E. 1980. Mszyce roślin sadowniczych Polski. PWN, Warszawa, 119 ss.

Emden H., Harrington R. 2007. The 14 aphid species of most agricultural importance. Aphis fabae (black bean aphid) p. 8-9. In: „Aphids as Crop Pests” (H.F. van Emden, R. Harrington, eds). CAB International, London, 699 pp.

Łabanowska B. 2007. Szkodniki na borówce wysokiej. http://www.ho.haslo.pl/article.php?id=3047. Dostep: 07.03.2013.

Łabanowska B. 2012. Szkodniki występujące na borówce i innych krzewach owocowych. s. 34-35. W: Materiały z Konferencji „Intensyfikacja uprawy krzewów jagodowych przez wdrażanie najnowszych wyników badań”. InHort, Skierniewice, 23 marca 2012, 61 ss.

Mitchell C., Brennan R., Cross J., Johnson S.N. 2011. Arthropod pests of currant and gooseberry crops in the U.K.: their biology, management and future prospects. Agr. Forest Entomol. 13 (3): 221-237.

Pansa M., Tavella L. 2008. Aphid population dynamics on highbush blueberry in relation to the spread of Blueberry scorch virus in Piedmont (NW Italy). Bull. Insectol. 61 (1): 205-206.

Ranger C., Johnson-Cicalese J., Polavarapu S., Vorsa N. 2006. Evaluation of Vaccinium spp. for Illinoia pepperi (Hemiptera: Aphididae) performance and phenolic content. J. Econ. Entomol. 99 (4): 1474-1482. 